\title{
Infiltrated SrTiO3:FeCr-based anodes for metalsupported SOFC
}

Blennow Tullmar, Peter; Persson, Åsa Helen; Nielsen, Jimmi; Reddy Sudireddy, Bhaskar ; Klemensø, Trine

Publication date:

2012

Link back to DTU Orbit

Citation (APA):

Blennow Tullmar, P., Persson, Å. H., Nielsen, J., Reddy Sudireddy, B., \& Klemensø, T. (2012). Infiltrated $\mathrm{SrTiO}_{3}$ :FeCr-based anodes for metalsupported SOFC. Poster session presented at 10 th European SOFC Forum, Luzern, Switzerland.

\section{General rights}

Copyright and moral rights for the publications made accessible in the public portal are retained by the authors and/or other copyright owners and it is a condition of accessing publications that users recognise and abide by the legal requirements associated with these rights.

- Users may download and print one copy of any publication from the public portal for the purpose of private study or research.

- You may not further distribute the material or use it for any profit-making activity or commercial gain

- You may freely distribute the URL identifying the publication in the public portal

If you believe that this document breaches copyright please contact us providing details, and we will remove access to the work immediately and investigate your claim 


\section{Infiltrated $\mathrm{SrTiO}_{3}: \mathrm{FeCr}$-based anodes for metal-supported SOFC}

\section{Peter Blennow, Åsa H. Persson, Jimmi Nielsen, Bhaskar R. Sudireddy, Trine Klemensø}

The concept of using highly electronically conducting backbones with subsequent infiltration of electrocatalytic active materials, has recently been used to develop an alternative SOFC design based on a ferritic stainless steel support. Testing and characterization of a metal-supported SOFC (MS-SOFC) where the anode backbone consists of a composite of Nb-doped $\mathrm{SrTiO}_{3}(\mathrm{STN})$ and $\mathrm{FeCr}$ are presented. The results indicate that the STN component in the anode seems to have a positive effect on the corrosion stability of the FeCr-particles in the anode layer. Since STN is only electronically conducting, it is suggested that this phase limits the access of oxygen (ions) to the stainless steel surface in the anode backbone, and thereby improves the corrosion stability. Additional work is required to optimize the microstructure and to investigate the long term stability.

Cell design and fabrication

Convell design is based on a multilayered structure obtainable by support (ferritic stainless steel alloy) and a cermet layer, containing electronically conducting ceramic particles $\left(\mathrm{Sr}_{0.99} \mathrm{Ti}_{0.9} \mathrm{Nb}_{0.1} \mathrm{O}_{3}, \mathrm{STN} 99\right)$ and $\mathrm{FeCr}$ particles, are co-sintered logether with an electrolyte. After co-sintering, the

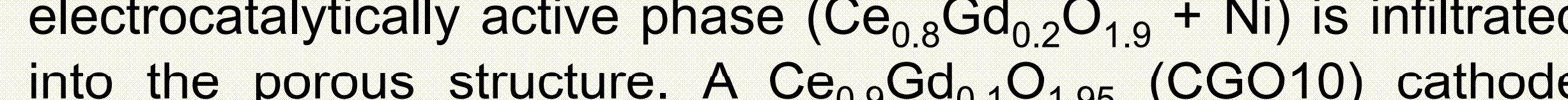
barrier layer (CBL) is deposited with PVD. As cathode $\left(\mathrm{La}_{0.6} \mathrm{Sr}_{0.4}\right)_{0.99} \mathrm{CoO}_{3-\delta}: \mathrm{Ce}_{0.9} \mathrm{Gd}_{0.1} \mathrm{O}_{2-\delta}$ composite was applied by screen printing
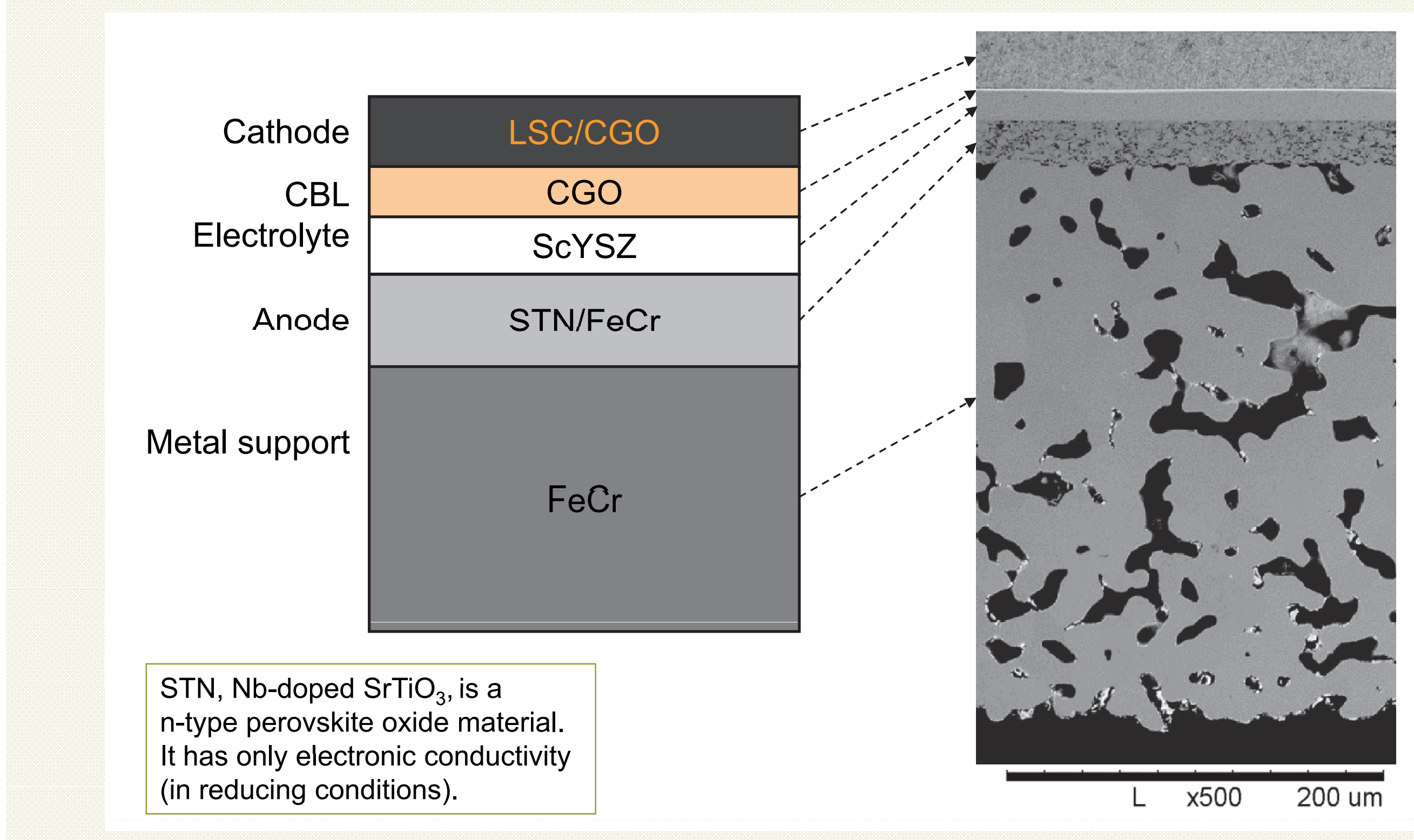

Schematic illustration and
the anode backbone layer.
Electrochemical characterization

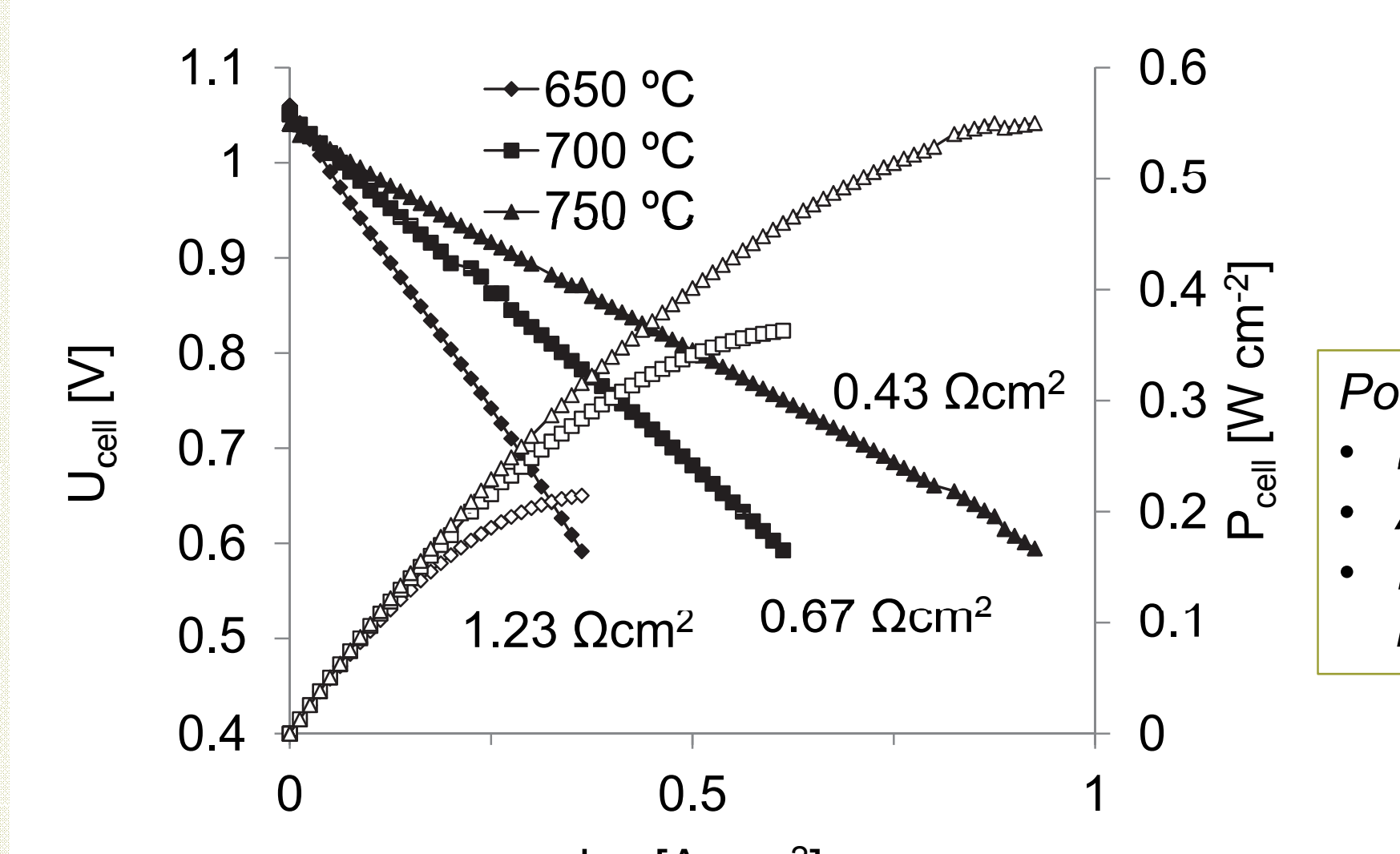

$\left.\operatorname{locel}_{1}^{0.5} \mathrm{~cm}^{2}\right]$

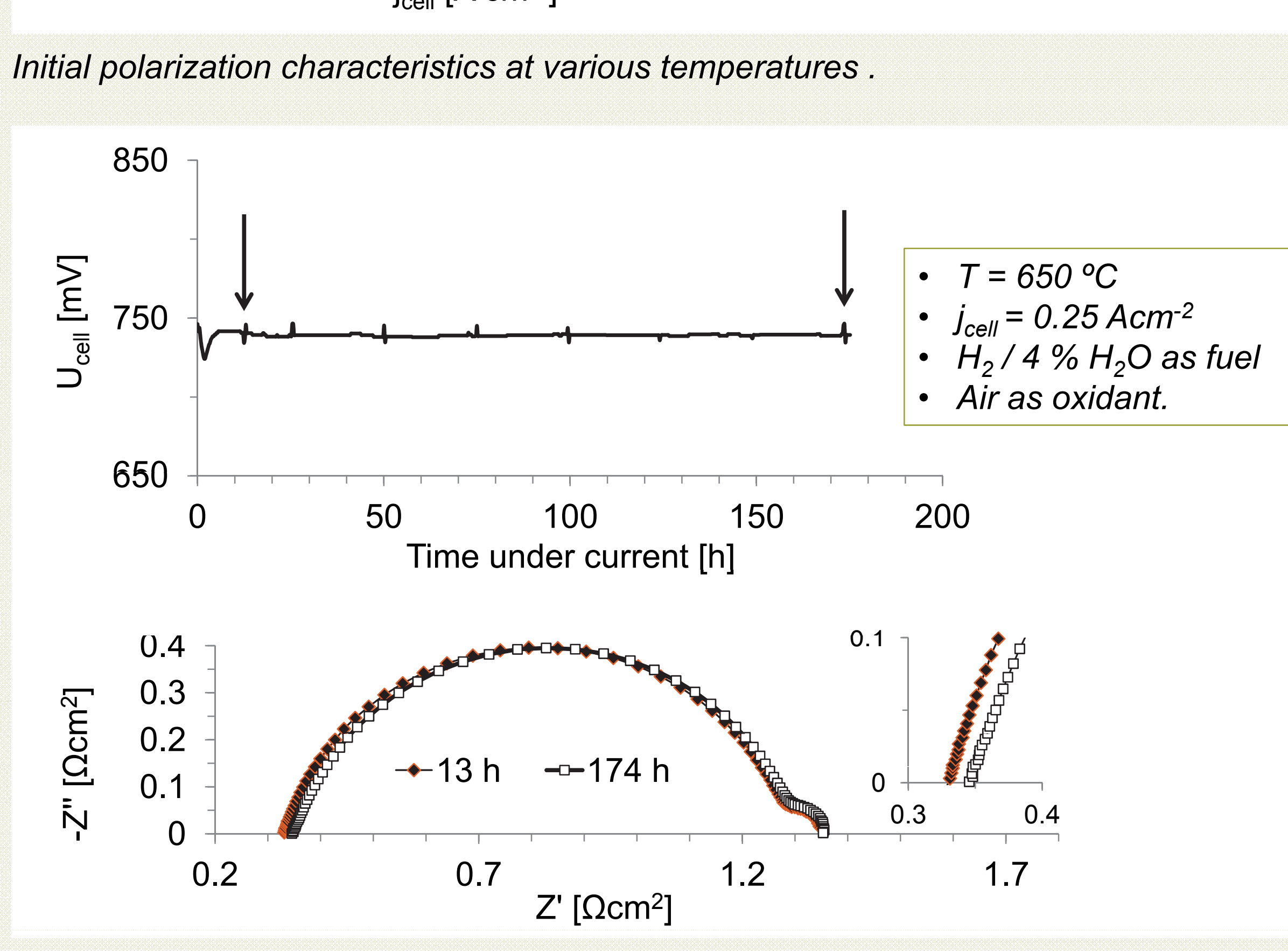

Galvanostatic durability curve (top) where the arrows indicate when EIS was
Microstructural characterization

An electrochemically tested cell with FeCr:YSZ-based backbone (our normal configuration) has been included for comparison to show the microstructural effect of the STN phase on the corrosion of the $\mathrm{FeCr}$ particles. A clear $\mathrm{Cr}_{2} \mathrm{O}_{3}$ scale is formed on the $\mathrm{FeCr}$ particles in the FeCr:YSZ anode (dark grey phase),
different behaviour is observed in the FeCr:STN case.

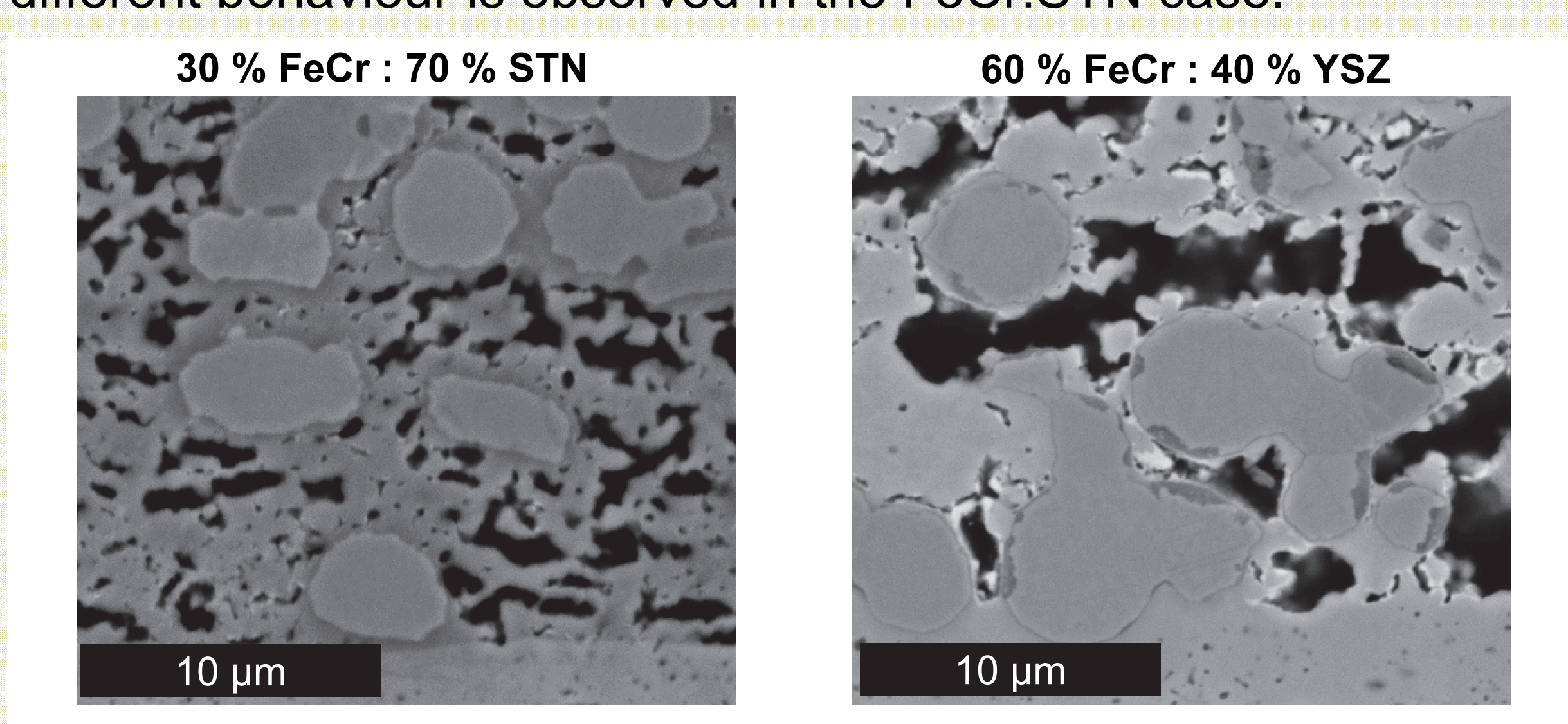

SEM images of fwo different types of anoded backbones in the MS-SOFC after
electrochemical testing. The cells had been tested with a similar test protocol.

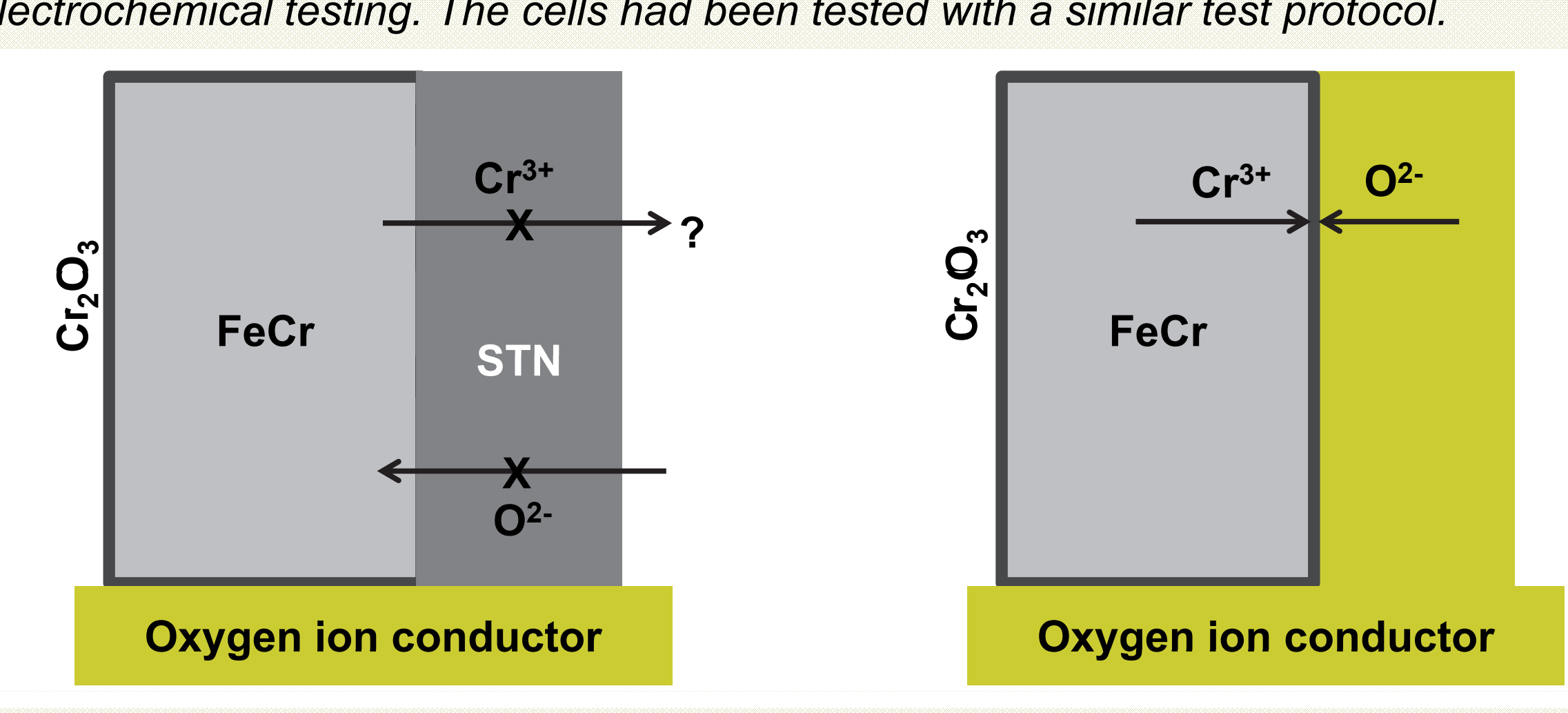

Tentative hyothesis for the improved corrosion stability of the STN:FeCr-based
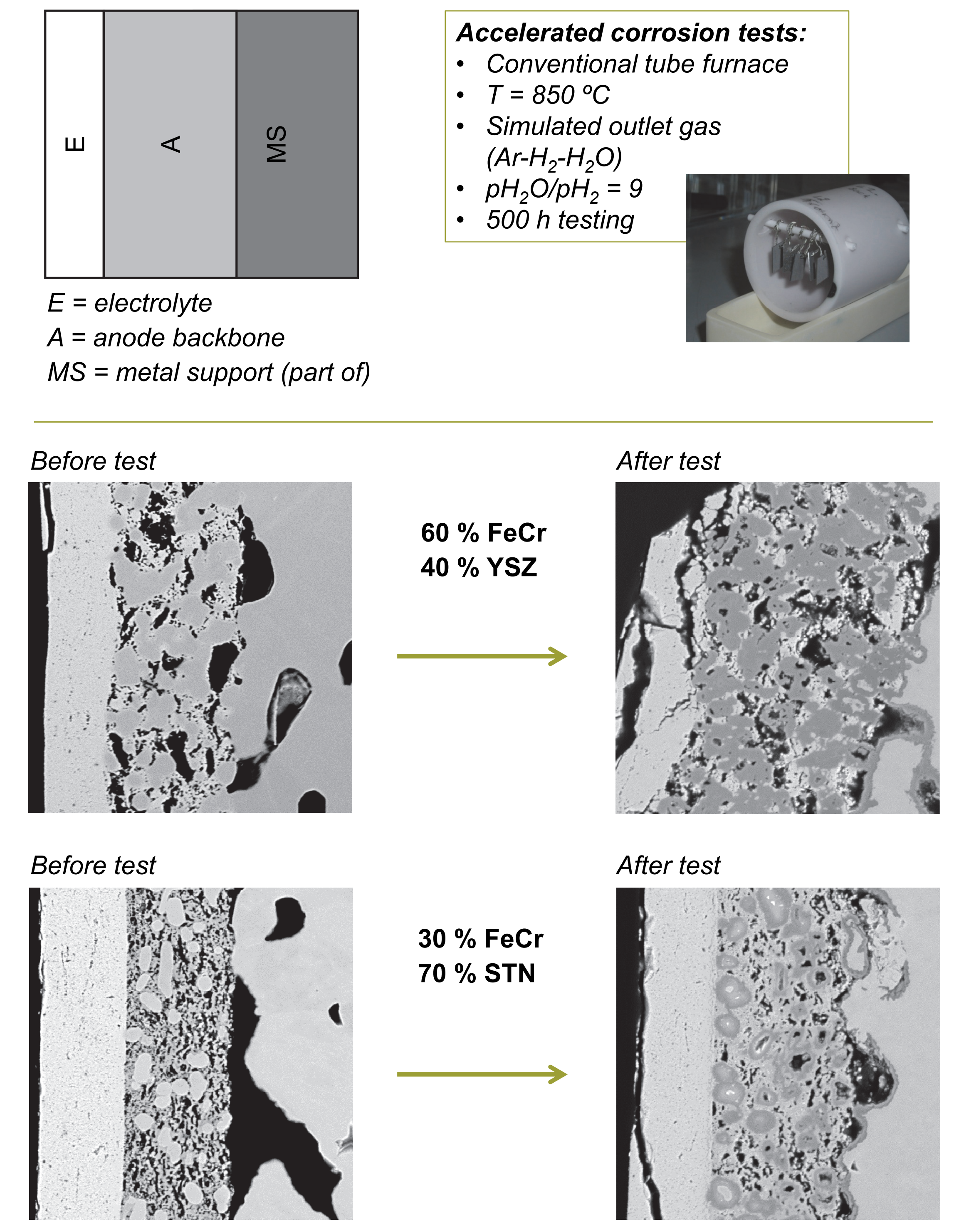

$30 \% \mathrm{FeCr}$
$70 \% \mathrm{STN}$
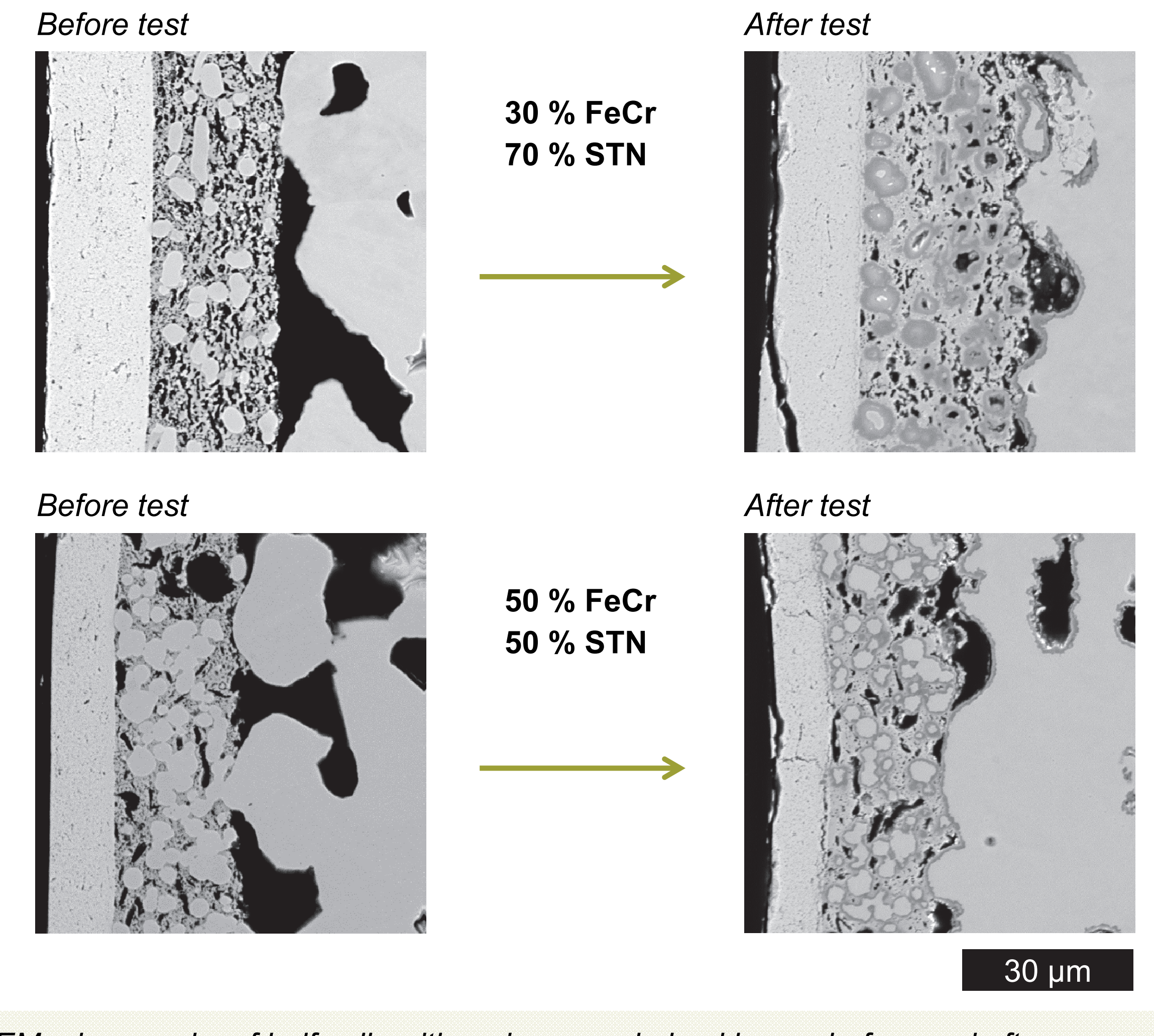

SEM micrographs of half cals
accelerated corrosion tests

ENERGINET/DK 